\title{
XỬ TRÍ VÕ̃ KÉN KHÍ PHỔI 2 BÊN Ở BỆH NHÂN ĐA KÉN KHÍ PHỔI: NHÂN MỘT TRƯờNG HỢP LÂM SÀNG VÀ TỔNG QUAN Y VĂN
}

\author{
Nguyễn Thành Luân*, Lê Quang Đình*, Luoong Việt Thắng*, Trần Thanh V y*
}

\section{TÓM TÁT}

Một bệnh nhân nam tuổi trung niên vào viện trong tình trạng khó thở sau tai nạn giao thông. Bệnh nhân được đặt dẫn lưu màng phổi 2 bên do tràn khí màng phổi 2 bên lượng nhiều, theo dõi tình trạng dẫn lưu 2 bên sau mổ ra khí kéo dài. Chụp cắt lớp vi tính độ phân giải cao chẩn đoán đa kén khí phổi 2 bên. Bệnh nhân đã được phẫu thuật thành công bằng đường tiếp cận mở ngực đường giữa xương ức cắt kén khí phổi 2 bên, bóc màng phổi thành 2 bên làm dính màng phổi. Sau mổ bệnh nhân hồi phục tốt cùng với có sự hỗ trợ giảm đau ngoài màng cứng và vật lý trị liệu hô hấp. Tràn khí màng phổi 2 bên do bệnh đa kén khí phổi là bệnh lý không thường gặp. Chụp cắt lớp vi tính độ phân giải cao giúp xác định bệnh lý này. Hiểu được các nguyên nhân bệnh sinh và lựa chọn phương pháp điều trị phù hợp sẽ cho kết quả lâu dài tốt, hạn chế biến chứng tràn khí màng phổi tái phát.

Tù khóa: Lymphangioleiomyomatosis (LAM), bệnh phổi mô bào Langerhans (PLCH), hội chứng Birt-Hogg-Dube (BHD), viêm phổi mô kẽ lympho bào (LIP)/viêm phế quản có kén(FB), và thâm nhiễm amyloidosis, tràn khí màng phổi

\section{SUMMARY}

\section{BILATERAL SPONTANEOUS PNEUMOTHORAX IN MULTIPLE CYSTIC LUNG DISEASES: A CASE REPORT AND REVIEW OF THE \\ LITERATURE}

A male patient complainted with shortness of breath after traffic accident and hospitalized in emegency department at University Medical Center.After that, the patient had diagnosed severe pneumothorax and had been indicated bilateral pleural drainage. In postoperative pleural drainge, he was still prolonged pneumothorax. High-resolution computed tomography (HRCT) shown that the patient had pneumothorax caused by multiple cystic lung disease. The Patient was successful surgery. We performed a full sternotomy with multiple blebs resection and pleurodesis done by pleurectomy into 2 sides. After surgery the patient recovered well along with the epidural pain relief and respiratory physiotherapy. Bilateral spontaneous pneumothorax caused by multiple cystic disease is a uncommon disease. HRCT helps to identify this condition. Understanding the causes of pathogenesis and choosing the appropriate treatment will have good long-term outcomes, limiting the recurrent pneumothorax.

Keywords: lymphangioleiomyomatosis, pulmonary Langerhans cell histiocytosis, BirtHogg-Dube syndrome, lymphocytic interstitial pneumonia/follicular bronchiolitis, amyloidosis, pneumothorax.

\footnotetext{
* Khoa Lồng ngưc Mạch máu - Bệnh viện Đại Học Y Dược TP.HCM Nguoòi chịu trách nhiệm khoa học: Ths Trần Thanh Vy Ngày nhận bài: 15/07/2018 - Ngày Cho Phép Đăng: 20/07/2018

Phản Biện Khoa học: PGS.TS. Đặng Ngọc Hùng

GS.TS. Lê Ngọc Thành
} 


\section{BỆNH ÁN LÂM SÀNG}

\section{HÀNH CHÁNH}

Họ tên: T.H Ty Giới: nam

Năm sinh: 1981

Địa chỉ: Cambodia

Nhập viện: 29/12/2017, xuất viện: $22 / 01 / 2018$

Lí do NV: đau ngực + khó thở

\section{BỆNH SỬ}

Cách nhập viện khoảng 1 tuần, bệnh nhân chấn thương đập ngực trong tai nạn giao thông, 2 ngày sau còn đau ngực nhiều, khó thở nhẹ, điều trị tại địa phương không giảm, còn khó thở + đau ngực tăng được chuyển đến bệnh viện ĐHYD TPHCM

Tiền sử: không hút thuốc lá, gia đình chưa ai từng bị tràn khí màng phổi hay bệnh phổi liên quan

\section{Tình trạng lúc NV:}

Bệnh tỉnh, tiếp xúc tốt, giao tiếp thông qua phiên dịch viên

Thở oxy qua canula 61/ph

Sinh hiệu: M 87, HA 110/80, SpO2 93\%, t0: 37

Tim đều rõ

Tam chứng galliard 2 phổi

Bụng mềm

Cận lâm sang: $X$ Quang ngực thẳng: tràn khí màng phổi 2 bên lượng trung bình - nhiều

Chẩn đoán: Chấn thương ngực kín biến chứng tràn khí màng phổi 2 bên lượng nhiều sau TNGT
Hướng xử trí cấp cứu: phẫu thuật cấp cứu dẫn lưu màng phổi 2 bên

Diển tiến sau mổ (từ 30/12 - 7/1)

Bệnh tỉnh

Tiếp xúc tốt

Không khó thở

Sinh hiệu ổn

ODL (P) hoạt động tốt, còn ra khí theo nhịp thở

ODL (T) hoạt động không hiệu quả

Tim đều rõ

Phổi giảm âm phổi trái

$X$-quang sau dẫn lưu: còn tràn khí màng phổi 2 bên

Ngày 8/1: Bệnh nhân được chỉ định chụp Ctscan ngực kết quả ghi nhận nhiều kén khí rải rác các thùy phổi 2 bên, vài kén khí đã vỡ, tràn khí màng phổi 2 bên lượng nhiều

Ngày 9/1 chúng tôi tiến hành hội chẩn khoa:

- Chẩn đoán: Đa kén khí phổi 2 bên - tràn khí màng phổi kéo dài/ HPN8 dẫn lưu màng phổi 2 bên, chấn thương ngực kín sau TNGT

- Hướng xử trí: chẻ xương ức giải quyết tổn thương phổi 2 bên + làm dính màng phổi

- Ngày 11/1 bệnh nhân được phẫu thuật chương trình chẻ xương ức khâu kén khí + làm dính màng phổi 2 bên

• Tường trình phẫu thuật: chẻ xương ức toàn phần, mở màng phổi trung thất vào khoang màng phổi 2 bên, thám sát thấy màng phổi 2 bên dày, xơ cứng, rất nhiều kén khí, bóng khí 
cả 2 bên phổi, kẹp cắt, khâu cột các kén khí thành 2 bên + hút áp lực âm liên tục sau mổ => lớn, nhận thấy không thể xử lý tất cả các làm dính khoang màng phổi 2 bên dự phòng thương tổn, quyết định lóc gần trọn màng phổi tái phát.

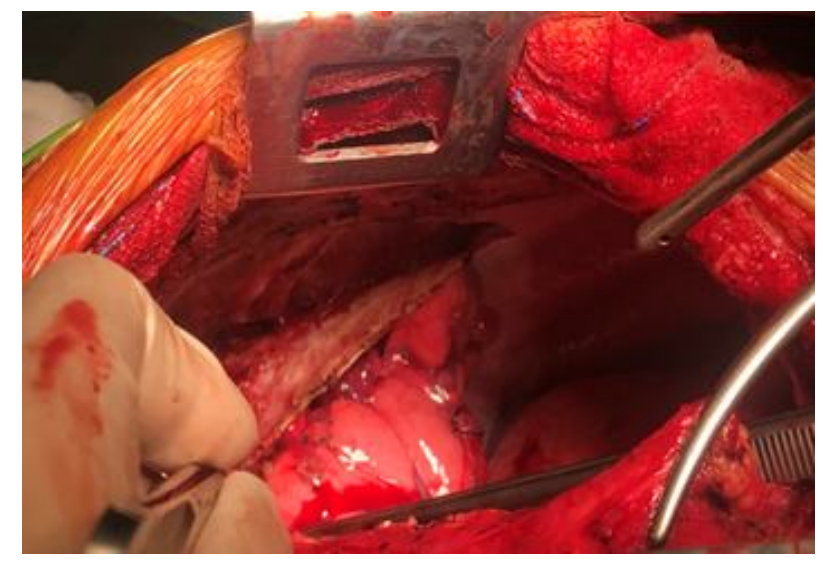

Bóc màng phổi tạng

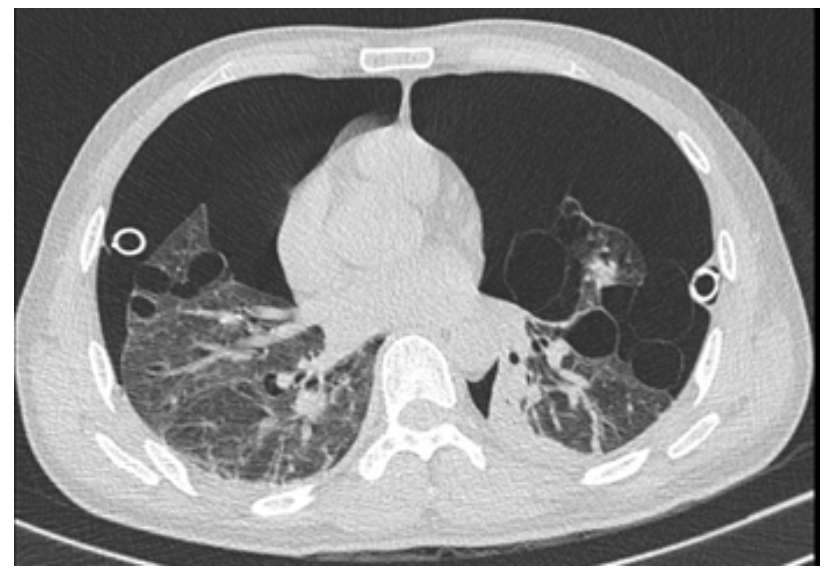

CTS can truớc mổ

Diễn tiến sau mổ: ngày 12/1 đến 21/1/2018 bệnh tỉnh, sinh hiệu ổn.

ODL hoạt động tốt.

Ra khí ít dần.

Đau giảm dần.

Duy trì giảm đau ngoài màng cứng 4 ngày sau mổ

Hút bình liên tục, vật lý trị liệu hô hấp tích cực

Rút ODL tại ngày hậu phẫu thứ 9 do ODL không ra thêm khí, phổi nở tốt

CTScan sau mổ: phổi 2 bên nở tốt, tràn khí màng phổi khu trú lượng ít, không máu đông màng phổi.

GPB sau mổ: kén khí phổi

Bệnh nhân được xuất viện vào ngày 22/1/2018.
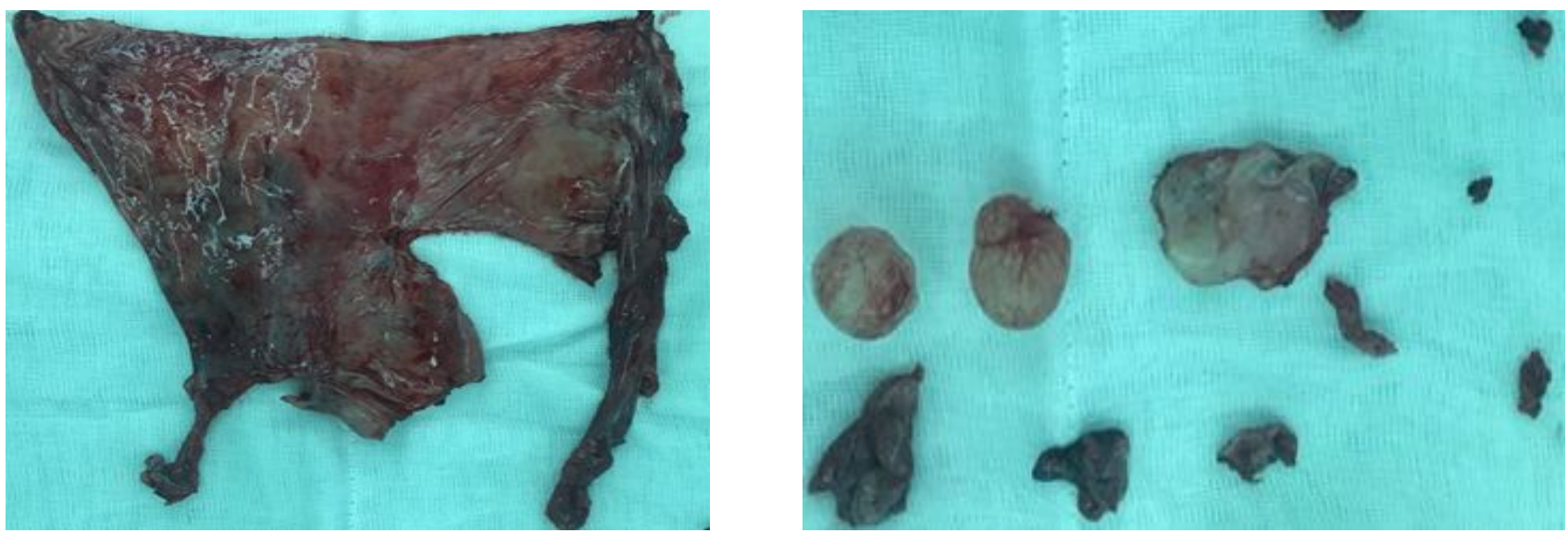

Màng phổi thành và bóng khí 


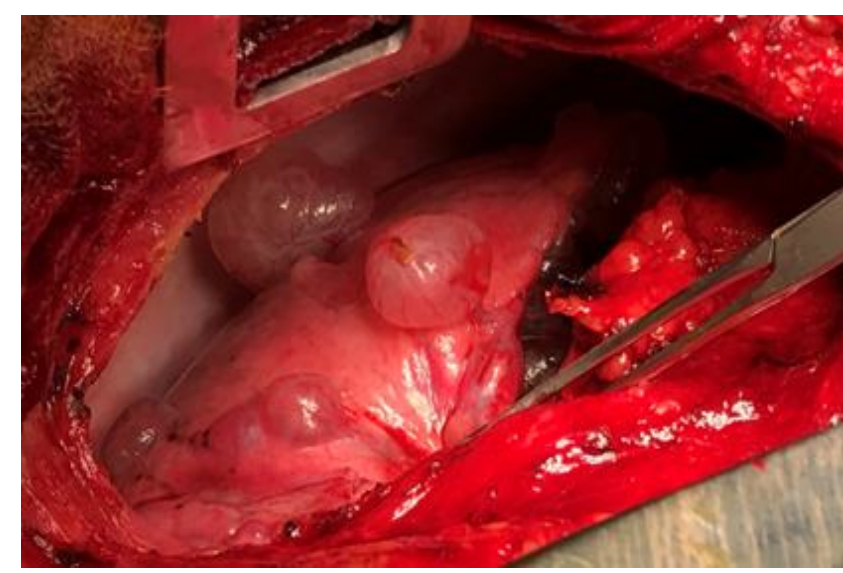

Bóng khí phổi 2 bên

KÉN KHÍ PHỔI -TỔNG QUAN Y VĂN

\section{GIỚI THIỆU}

Kén khí phổi là nhóm các bệnh ở phổi được đặc trưng bởi sự hiện diện của một hoặc nhiều kén - là những vùng sáng do khí hoặc vùng giảm đậm độ, được bao bọc mởi một thành mỏng (thường $<2 \mathrm{~mm}$ ) và phân biệt rõ ràng với mô phổi bình thường. Chẩn đoán lâm sàng của bệnh phổi mô kẽ đã tăng lên nhờ vào việc sử dụng chụp $\mathrm{CT}$ độ phân giải cao và thăm khám bệnh sức khỏe định kỳ. Kén khí rất hiếm gặp ở bệnh nhân không có triệu chứng $<55$ tuổi nhưng tỉ lệ này tăng dần theo độ tuổi ${ }^{[2]}$. Bệnh kén khí phổi là bệnh rất đa dạng trong số nhiều bệnh lý tại phổi, nó xuất phát từ rất nhiều các nguyên nhân nhưng thường có chung đặc điểm về mặt biến dạng cấu trúc giải phẫu của kén khí. Dựa vào các bệnh nguyên phức tạp của nó, bệnh kén khí phổi có thể được phân loại dựa vào các yếu tối sinh lý bệnh, cơ chế, yếu tố bẩm sinh, gene, nhiễm trùng, viêm, tăng sinh tế bào lympho, U tân sinh, và liên quan đến thuốc lá. Bệnh kén khí phổi phải được chẩn đoán phân biệt với bệnh cảnh khí phế thủng, tổn thương

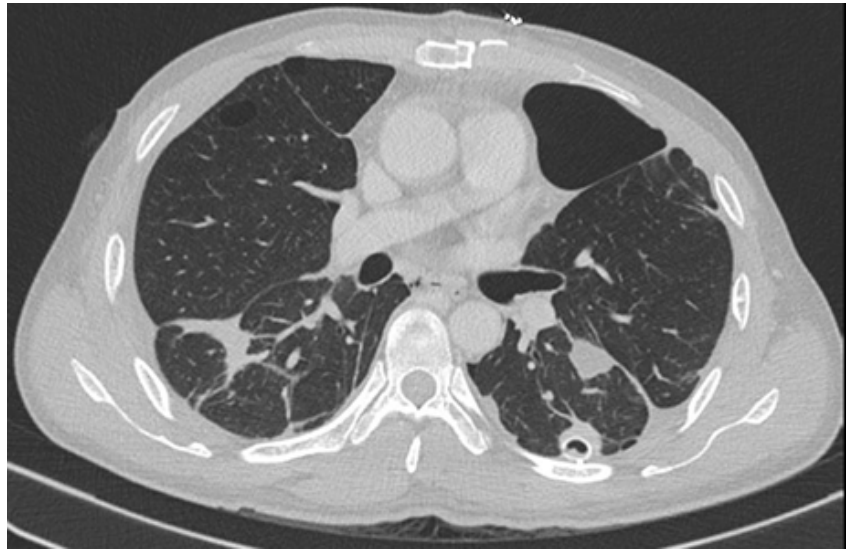

\section{CTScan sau mổ}

dạng hang, bọng nước, thoát vị phổi và hình dạng phổi tổ ong do xơ hóa, tất cả các đặc điểm này đều thấy tăng sáng nên có thể nhầm hình ảnh giả kén khí phổi. Việc phân biệt với kén khí phổi có thể dựa vào độ dày của thành, kích thước của khí trong khoang, vị trí giải phẩu, và $\mathrm{xu}$ hướng tạo của kén thành cụm kén. Bảng 1 liệt kê kén và sự thay đổi của hình ảnh giả kén trong $\mathrm{X}$ quang và $\mathrm{CT}$ độ phân giải cao ${ }^{[5],[12]}$

Các nguyên nhân thường gặp gây đa kén khí phổi bao gồm Lymphangioleiomyomatosis (LAM) , bệnh phổi mô bào Langerhans (PLCH), hội chứng Birt-Hogg-Dube (BHD), viêm phổi mô kẽ lympho bào (LIP)/viêm phế quản có kén(FB), và thâm nhiễm amyloidosis ${ }^{[3]}$

\section{CƠ CHẾ HÌNH THÀNH KÉN}

Bệnh sinh của sự hình thành kén trong phổi là chưa rõ. Có một vài cơ chế được đề xuất dựa vào nhiều quá trình sinh lý bệnh và các bệnh điển hình có liên quan đến cơ chế được đưa ra. Tắc nghẽn dạng van một chiều "checkvalve" trong phổi dẫn đến hậu quản làm phồng lên phần đầu xa phế nang được xem là cơ chế được biết đến nhiều nhất trong bệnh kén khí phổi và có liên quan đến các bệnh như viêm 
phế quản có kén, $U$ di căn, thoát vị phổi, LAM và bệnh phổi mô bào Langerhans. Tuy nhiên, kén ở LAM hoặc bệnh phổi mô bào Langerhans trở nên nhỏ hơn khi chụp CT ở thì thở ra, điều này gợi ý các tổn thương kén này có liên quan đến nhiều mức độ. Thiếu máu cũng là cũng có thể tạo nên sự thay đổi kén trong phổi.

Sự tắc nghẽn các mao mạch nhỏ cấp máu cho tiểu phế quản tận dẫn đến hoạt tử đường thông khí và gây dãn nỡ do thiếu máu. Cơ chế phân tử cũng đồng thời được gợi ý khi có nguyên bào sợi tăng sản sinh men tiêu hủy cấu trúc nền (Matrix metalloproteinase (MMP)), enzyme giáng hóa cấu trúc nền, và podoplanin $\left(\mathrm{D}_{2-40}\right)$ gây ra tái cấu trúc mô phổi. LAM, bệnh phổi mô bào Langerhans và bệnh lắng đọng chuỗi phân tử nhẹ là các bệnh đại diện cho cơ chế phân tử này.

Cuối cùng, đột biến gene cũng được cho là có vai trò quan trọng trong việc hình thành kén khí phổi, đặc biệt là trong hội chứng BHD. Việc tìm hiểu về mặt giải phẫu bệnh của hội chứng BHD (không có sự hiện diện của tràn khí màng phổi) bao gồm kén mà nó tiếp giáp với vách gian tiểu thùy, không có tình trạng viêm nhiễm đặc trưng, gợi ý đến việc bất thường ở nơi tiếp nối giữa các vách phế nang. Hội chứng BHD cũng có liên quan đến đột biến gene Folliculin (FLCN). Nghiên cứu mô miễn dịch của sự biểu hiện FLCN trong mô phổi từ các bệnh nhân này cho thấy có rất ít Surfactant protein $\mathrm{C}(\mathrm{SP}-\mathrm{C})$ biểu hiện trên tế bào biểu mô phế nang. Việc mất đi chức năng của FLCN trong mô hình thử nghiệm trên chuột ở hội chứng BHD dẫn đến tăng sự chết theo chu trình của tế bào biểu mô phế nàng và nở lớn phế nang, điều này gợi ý đến vai trò của FLCN trong sự hình thành kén ${ }^{[15]}$

\section{Bảng 1. Phân loại các thương tổn tại phổi ${ }^{[7]}$}

\section{Tổn thương Định nghĩa tổn thương}

\section{Kén Là vùng nhu mô tròn sáng phân biệt với các mô phổi bình thường} Thành mỏng $(<2 \mathrm{~mm})$

Khí phế thủng Dãn lâu dài vùng khí đầu xa đến tiểu phế quản tận không có thành

Hang Vùng khí đồng nhất, dạng khối hoặc nốt

Đặc trưng bởi thành dày

Đôi khi có chứ mức dịch-khí

Bóng khí Vùng khí (kích thước $>1 \mathrm{~cm}$ ) với tiêu cự tròn tăng sáng, bao bởi thành mỏng $(<2 \mathrm{~mm})$

Túi khí Kích thước nhỏ $(<1 \mathrm{~cm})$, vùng khí nằm trong lá tạng hoặc vùng dưới khoang màng phổi

Thoát vị phổi Thành mỏng, vùng khí nằm bên trong phổi do viêm, chấn thương, hít phải dịch hydrocarbon

Hình ảnh tổ ong Dưới khoang màng phổi, nhiều chùm kén, thường đường kính từ $3-10 \mathrm{~mm}$ phổi do xơ hóa với thành rõ

Gợi ý bệnh phổi giai đoạn cuối 


\section{TIẾP CẬN CHẨN ĐOÁN}

Phân tích ban đầu bằng các phương diện hình ảnh học về sự thay đổi của kén khí trên phổi bệnh. Chụp CT đô phân giải cao miêu tả một vài đặc điểm liên quan của tổn thương dạng kén, như là sự phân bố của nó (ngẫu nhiên/khuếch tán, hoặc ở vùng đặc hiệu). Trong khi các kén ở LAM, LIP, FB, và thâm nhiễm amyloid cho hình ảnh phân bố khuếch tán hoặc ngẫu nhiên, thì kén ở PLCH thường nằm ở vùng trên hoặc giữa chiếm ưu thế hơn và kén ở hội chứng BHD có phân bố ở vùng đáy/ngoại biên/dưới màng phổi. Độ dày của thành kén là một đặc điểm hữu ích cho việc chẩn đoán. Cấu trúc bên trong dạng rắn ở kén phổi thì thường là FB, LIP hoặc BHD. Bên cạnh đánh giá hình ảnh học kén khí, còn có các thông tin khác từ hình ảnh học bao gồm tràn dịch màng phổi, nốt nhu mô phổi và hình ảnh kính mờ.

Chẩn đoán mô học nhờ nội soi sinh thiết phế quản, sinh thiết phổi qua phế quản, sinh thiết trong phẩu thuật nội soi lồng ngực VATS hoặc thậm chí mở ngực sinh thiết, việc này tùy thuộc vào tình trạng bệnh nhân và lợi ích của chẩn đoán. Về mặt quy ước nhuộm gram soi kính hiển vi là hematoxylin
- eosin, kén thật sẽ có một lớp biểu mô trên bền mặt, trong khi các kén giả không có tế bào biểu mô bao phủ. Kén ở hội chứng BHD phân bố ở trong nhu mô phổi hoặc ở vùng đáy, trong khi đối với khí phế thủng thì thường ở vùng đỉnh hoặc có phân bố ở vùng tiểu thùy trung tâm. Khi quan sát dưới kính hiển vi, LAM, PLCH hoặc U bao gồm tăng sinh các tế bào bất thường điều này đòi hỏi phải nhuộm đặc hiệu hoặc làm miễn dịch tế bào. Viêm phổi mạn tính và bệnh mô liên kết - bệnh phổi mô kẽ thường có hình ảnh xơ hóa và thâm nhiễm viêm mạn tính. Ở LAM, việc phát hiện tế bào hắc tố $\left(\mathrm{HMB}_{-45}\right)$ và ở PLCH sự biểu hiện của $\mathrm{CD}_{1} \mathrm{~A}$, giúp ích cho việc chẩn đoán. khúc xạ kép Apple-Green ở mô được nhuôm với Congo đỏ là rất quan trọng trong việc phân biệt thâm nhiễm Amyloid với LCDD. Nhờ vào sự phát triển của hình ảnh học và bệnh học, độ dương tính với các markers sinh học như yếu tố tăng trưởng nội mô mạch máu (VEGF-D) và MMPs, sự thay đổi trong bằng chứng gene, và tình trạng bệnh đi kèm là rất hữu ích trong việc chẩn đoán ${ }^{[15]}$

\section{NGUYÊN NHÂN GÂY BỆNH}

Bảng 2. Phân biệt các nguyên nhân gây bệnh đa kén khi phổi ${ }^{[15]}$

\begin{tabular}{|c|c|c|c|c|c|c|c|}
\hline \multirow{2}{*}{$\begin{array}{c}\text { Các } \\
\text { bệnh lý }\end{array}$} & \multirow{2}{*}{ Tuổi } & \multicolumn{3}{|c|}{ Hình ảnh CTScan } & \multirow{2}{*}{ Sinh thiết } & \multirow{2}{*}{ Lâm sàng } & \multirow{2}{*}{ Điều trị } \\
\hline & & Hình dạng & Phân bố & khác & & & \\
\hline LAM & 35 & Tròn, mịn & Lan tỏa & & $\begin{array}{l}\text { Tế bào LAM } \\
\text { HMB- } 45(+)\end{array}$ & $\begin{array}{l}\text { Bệnh xơ cứng củ } \\
\text { phức tạp (TSC), } \\
\text { bướu mỡ-cơ- } \\
\text { mạch (AML), } \\
\text { Nữ }>>\text { nam }\end{array}$ & $\begin{array}{l}\text { Úc chết } \\
\text { mTOR }\end{array}$ \\
\hline
\end{tabular}




\begin{tabular}{|c|c|c|c|c|c|c|c|}
\hline PLCH & $2-40$ & $\begin{array}{l}\text { Đa dạng, } \\
\text { không theo } \\
\text { quy tắc }\end{array}$ & $\begin{array}{c}\text { Thùy trên } \\
\text { và thùy } \\
\text { dưới }\end{array}$ & $\begin{array}{c}\text { Nốt, } \\
\text { khoang }\end{array}$ & $\begin{array}{c}\text { Tế bào } \\
\text { Langerhans, } \\
\text { CD1a (+) }\end{array}$ & $\begin{array}{c}\text { Hút thuốc, Nữ = } \\
\text { Nam, đột biến } \\
\text { BRAF }\end{array}$ & $\begin{array}{l}\text { Úc chế } \\
\text { miễng } \\
\text { dịch, ức } \\
\text { chết } \\
\text { BRAF }\end{array}$ \\
\hline BHD & $3-40$ & $\begin{array}{l}\text { Tròn, dạng } \\
\text { thấu kính }\end{array}$ & $\begin{array}{c}\text { Phần đáy, } \\
\text { phần giữa, } \\
\text { dưới } \\
\text { màng phổi }\end{array}$ & $\begin{array}{l}\text { Dấu } \\
\text { kính } \\
\text { mờ, } \\
\text { dày } \\
\text { thành }\end{array}$ & Không đặc hiệu, & $\begin{array}{l}\text { Da, u thận, đột } \\
\text { biến FLCN, đột } \\
\text { biến gene trội }\end{array}$ & $\begin{array}{c}\text { Úc chế } \\
\text { miễn } \\
\text { dịch }\end{array}$ \\
\hline LIP/FB & $4-70$ & $\begin{array}{c}\text { Cấu trúc bên } \\
\text { trong mô }\end{array}$ & $\begin{array}{c}\text { Ngẫu } \\
\text { nhiên, } \\
\text { ngoại vi } \\
\text { mạch máu }\end{array}$ & \begin{tabular}{|c} 
Nốt, \\
canxi \\
hóa các \\
khoang
\end{tabular} & $\begin{array}{l}\text { Xâm nhập } \\
\text { lympho bào }\end{array}$ & $\begin{array}{c}\text { Rối loạn tự } \\
\text { miễn, nữ > nam }\end{array}$ & $\begin{array}{l}\text { Úc chế } \\
\text { miễn } \\
\text { dịch }\end{array}$ \\
\hline $\begin{array}{c}\text { Amyloi } \\
\text { dosis }\end{array}$ & - & Tròn & $\begin{array}{l}\text { Ngẫu } \\
\text { nhiên }\end{array}$ & & $\begin{array}{c}\text { khúc xạ kép } \\
\text { Apple-Green ở } \\
\text { mô được nhuôm } \\
\text { với Congo đỏ }\end{array}$ & $\begin{array}{c}\text { Đa u tủy, } \\
\text { lymphoma, bệnh } \\
\text { Sjogren }\end{array}$ & $\begin{array}{l}\text { Úc chế } \\
\text { miễn } \\
\text { dịch }\end{array}$ \\
\hline
\end{tabular}

\section{BIẾN CHÚNG TRÀN KHÍ MÀNG PHỔI ${ }^{[9],[13]}$}

Đa kén khí phổi là nguyên nhân thường gặp tràn khí màng phổim(TKMP) tự phát và chiếm gần $10 \%$ trong số bệnh nhân tràn khí màng phổi tự phát nguyên phát ${ }^{[4],[8]}$

\subsection{Lymphangioleiomyomatosis}

55-63\% bệnh nhân mắc bệnh LAM đã từng bị tràn khí màng phổi trong cuộc đời, và tới $40 \%$ bệnh nhân vào viện với bệnh cảnh TKMP được chẩn đoán bệnh LAM. Khoảng 80\% bệnh nhân TKMP lúc nghỉ ngơi và vận động nhẹ. Những bệnh nhân có kích thước bóng khí $>5 \mathrm{~mm}$ và có tiền sử hút thuốc lá sẽ tăng nguy cơ TKMP. Thay kỳ cũng làm tăng nguy cơ của TKMP. TKMP chiếm tỷ lệ cao đáng kế đối với tỷ lệ bệnh nhân nhập viện lại trong số bệnh nhân LAM.

\section{Hướng xư trí:}

Không những chỉ có bệnh nhân bị LAM mà tất cả bệnh nhân đa kén khí phổi nếu có triệu chứng của TKMP thỉ phải được xử lý ngay lập tức. Ngưng hút thuốc được khuyến khích mạnh mẽ. Và vì tỷ lệ tái phát cao nên làm dính màng phổi nên được thực hiện ngay từ lần đầu tiên bị TKMP hơn là chờ tái phát. Trong một nghiên cứu cho thấy TKMP một bên tái phát khoảng $66 \%$ nếu điều trị bảo tồn, nhưng nó sẽ giảm xuống $27 \%$ nếu có làm dính phổi bằng hóa chất và $32 \%$ nếu làm dính phổi bằng phẫu thuật.

Một vấn đề nhiều nhà lâm sàng quan tâm là làm dính màng phổi có thể tăng nguy cơ chảy máu và kéo dài thời gian phẫu thuật. Tuy nhiên những điều này không có ảnh hưởng đến kết 
quả điều trị bệnh nhân về cả phương diện tỷ lệ tử vong và kéo dài thời gian nằm viện và một điều quan trọng là nó không chống chỉ định cho ghép phổi sau này.

\subsection{Pulmonary langerhans cell histiocytosis}

Gần $15-20 \%$ bệnh nhân với PLCH bị TKMP. Hơn $60 \%$ trong số đó sẽ có hơn 1 lần TKMP, tỷ lệ tái phát cho TKMP cùng bên khoảng $56 \% .11 \%$ bệnh nhân vào viện với bệnh cảnh TKMP được chẩn đoán PLCH. Tràn khí màng phổi 2 bên có thể xảy ra và thường giai đoạn sơ sinh. Tình trạng tràn khí màng phổi sau ghép phổi ở bệnh nhân PLCH cũng được báo cáo.

\section{Huớng xư trí:}

Cũng không ngoại lệ vì sự tái phát TKMP cao, nên làm dính phổi nên được thực hiện trong lần đầu tiên phát hiện bệnh. Theo Mendez và cộng sự thấy có $58 \%$ bệnh nhân tái phát khi điều trị bảo tồn, và $0 \%$ bệnh nhân tái phát khi làm dính phổi bằng phẫu thuật. Dặn bệnh nhân ngưng hút thuốc lá, ức chế miễn dịch và liệu pháp hóa trị củng còn nhiều tranh luận trong vai trò điều bị bệnh nhân $\mathrm{PLCH}$. Bên cạnh đó thì những nghiên cứu gần nay thì đột biến mitogen-activated protein kinase có vai trò trong điều trị.

\subsection{Hội chứng birt-hogg-dubé}

Bệnh nhân bị hội chứng $\mathrm{BHD}$ thì có nguy cơ TKMP cao gấp 50 lần ở những bệnh nhân nhóm chứng cùng tuổi. gần đây có 2 nghiên cứu cho thấy rằng $5-10 \%$ bệnh nhân bị TKMP mắc BHD. Những bệnh nhân TKMP do BHD thường ở độ tuổi 30 . Tuy nhiên có một số nghiên cứu báo cáo gặp ở trẻ em cũng như bệnh nhân lão. Số lượng bóng khí, kích thước, tổng thể tích bóng khí, tiền sử gia đình có TKMP đều liên quan tới việc tăng nguy cơ TKMP. TKMP tái phát gần $75-80 \%$.

\section{Hưởng xủ trí:}

Làm dính màng phổi có thể làm giảm nguy cơ tràn khí màng phổi tái phát một nửa (30\% nếu làm dính màng phổi và $60 \%$ tái phát nếu điều trị bảo tồn). Một điều quan trọng là ở bệnh nhân BHD thường không dẫn đến suy hô hấp tiến triển do đó các mối quan tâm liên quan đến biến chứng của làm dính màng phổi ảnh hướng đến vấn đề ghép phổi trong tương lai sẽ không ảnh hưởng ở nhóm bệnh nhân này.

\section{Bảng 3. Đặc điểm tràn khí màng phổi ở nhóm bệnh nhân đa kén khí phổi}

\begin{tabular}{lccc}
\hline \hline \multicolumn{1}{c}{ Lâm sàng } & LAM & PLCH & BHD \\
\hline \hline Tuổi xuất hiện tràn khí lần đầu & 35 & 29 & 37 \\
Tỷ lệ tràn khí màng phổi & $55-73 \%$ & $15-20 \%$ & $24-76 \%$ \\
TKMP là biểu hiện bệnh & $82 \%$ & $69 \%$ & $65 \%$ \\
Tràn khí màng phổi 2 bên & $4 \%$ & $12.5 \%$ & $5 \%$ \\
Tỷ lệ tràn khí tái phát cùng 1 bên & $71 \%$ & $56 \%$ & $73 \%$ \\
Tỷ lệ tái phát tràn khí đối bên & $74 \%$ & $29 \%$ & $48-71 \%$ \\
Tỷ lệ tái phát cùng bên khi điều trị bảo tồn sau lần đầu tràn khí & $66 \%$ & $58 \%$ & $63 \%$ \\
Tỷ lệ tái phát cùng bên khi điều trị bảo tồn sau lần thứ 2 tràn khí & $60 \%$ & & $93 \%$ \\
Tỷ lệ tái phát cùng bên sau làm dính phổi bằng hóa học & $27 \%$ & & $30 \%$ \\
Tỷ lệ tái phát cùng bên khi làm dính phổi bằng phẫu thuật & $32 \%$ & $0-20 \%$ & $35 \%$ \\
\hline \hline
\end{tabular}




\section{BÀN LUẬN}

Trong trường hợp bệnh nhân của chúng tôi trẻ,không có tiền căn hút thuốc lá vào viện với bệnh cảnh tràn khí màng phổi 2 bên sau chấn thương và chụp khi chụp cắt lớp vi tính độ phân giải cao có hình ảnh của đa kén khí phổi 2 bên, có hình ảnh bóng khí đã vỡ. Những hướng dẫn hiện tại không khuyến cáo dùng CTScan tầm soát cho lần đầu tiên tràn khí màng phổ ${ }^{[9]}$. Tuy nhiên những nghiên cứu gần đây cho thấy việc chụp CTScan có độ phân giải cao ở những bệnh nhân tràn khí màng phổi cho thấy nhiều lợi ích vì chẩn đoán sớm các bệnh lý LAM, $\mathrm{BHD}, \mathrm{PLCH}$ để có chiến lược làm dính màng phổi thì đầu vì nguy cơ tái phát cao ở nhóm bệnh nhân này.

Nhận định đây là một trường hợp đa kén khí phổi 2 bên có biến chứng tràn khí màng phổi kéo dài và đánh giá nguy cơ tái phát sau điều trị bảo tồn rất cao nên đường tiếp cận mở ngực giữa xương ức là được tiếp cận được chọn xử trí được thương tổn 2 bên. Chúng tôi cũng tiến hành làm dính phổi bằng phương pháp bóc màng phổi thành 2 bên và cùng với giảm đau ngoài màng cứng và vật lý trị liệu hô hấp tích cực sau mổ thì lâm sàng bệnh nhân cải thiện, $\mathrm{X}$ quang và $\mathrm{CT}$ scan sau mổ phổi nở tốt và không có biến chứng chảy máu sau mổ hay máu đông màng phổi.

Almoosa và cộng sự báo cáo có $31 \%$ bệnh nhân có chảy máu chu phẫu khi làm dính màng phổi và trong số đó chỉ có $50 \%$ bệnh nhân mở ngực lại. Qua nhiều nghiên cứu việc làm dính phổi cho thấy giảm biến chứng tràn khí màng phổi tái phát động thời không làm kéo dài thời gian nằm viện cũng như tỷ lệ tử vong chu phẫu và ảnh hưởng làm dính phổi lên sự ghép phổi sau này cũng không chống chỉ định vì nhìn chung biến chứng chảy máu khi ghép kiểm soát được ${ }^{[1]}$.

Vì nguy cơ TKMP tái phát sau khi làm dính màng phổi, cũng như nguy cơ dính phổi dễ gây biến chứng cho ghép phổi trong tương lai thì kỹ thuật bao bọc toàn bộ màng phổi (total pleural covering -TPC) đã ra đời bằng việc bọc màng phổi tạng bằng màng lưới sinh học "Oxidized cellulose mesh" (ROC) sau đó dùng fibrin glue để làm dính và thực hiện dưới sự hổ trợ của nội soi lồng ngực VATS bởi Kurihara và cộng sự, đã hứa hẹn mang lại kết quả tốt trong việc phòng ngừa tràn khí màng phổi mà không làm giảm chức năng phổi hoặc hình thành biến chứng dính nghiêm trọng ${ }^{[11]}$. Trong một nghiên cứu gần đây liên quan đến 43 bệnh nhân mắc bệnh LAM, TPC có tỷ lệ tái phát TKMP (26\%) tương đương với làm dính màng phổi truyền thống. Ứng dụng thành công TPC cũng đã được báo cáo trong bệnh nhân mắc PLCH, BHD và hội chứng Ehlers-Danlos Syndrome ${ }^{[14],[10]}$.

Ngoài ra làm dính phổi bằng máu, trong đó máu tự thân của bệnh nhân được bơm qua ống dẫn lưu kết quả bước đầu cho thấy có hiệu quả với tỷ lệ tràn khí màng phổi tái phát 15,6$18,2 \%$. Uu điểm của kỹ thuật này là tránh được gần như hoàn toàn các phản ứng phụ liên quan đến làm dính màng phổi điển hình như đau và sốt. Tuy nhiên việc đưa máu vào một khoang vô trùng khác có thể làm tăng nguy cơ biến chứng nhiễm trùng vì thế những kỹ thuật thay thế này cần được nghiên cứu kỹ hơn trước khi sử dụng rộng rãi ở những bệnh nhân bệnh lý đa kén khí phổi ${ }^{[6]}$. 


\section{KẾT LUẬN}

Đa kén khí phổi là bệnh cảnh cần đươc chẩn đoán sớm ở bệnh nhân tràn khí màng phổi tự phát nguyên phát và cần chẩn đoán được nguyên nhân cũng như phát hiện các bệnh lý tiềm ẩn. Chụp cắt lớp vi tính có độ phân giải cao cho thấy có nhiều lợi ích đối với bệnh nhân TKMP tự phát mang lại hiệu quả điều trị cao. Tỷ lệ tái phát cao TKMP ở bệnh nhân đa kén khí phổi nếu điều trị bảo tồn vì thế làm dính màng phổi nên được tiến hành thì đầu và làm dính màng phổi không chống chỉ định cho ghép phổi. Đường tiếp cận xử trí thương tổn trong đa kén khí phổi 2 bên cần được cân nhắc kỹ trước phẫu thuật và đường mở giữa xương ức là một sự lựa chọn, bên cạnh đó làm dính màng phổi bằng phẫu thuật bóc màng phổi tạng mang lại hiệu quả tốt cho bệnh nhân. Vấn đề điều trị nội khoa đi kèm và hiệu quả của các kỹ thuật thay thế để giảm nguy cơ tái phát của tràn khí màng phổi cần được nghiên cứu nhiều hơn trong tương lai.

\section{TÀI LIỆU THAM KHẢO}

1. Almoosa KF, Ryu JH, Mendez J, Huggins JT, Young LR, Sullivan EJ, Maurer J, et al. management of pneumothorax in lymphangioleiomyomatosis: effects on recurrence and lung transplantation complications. Chest.2006;129 (5):1274-1281.

2. Copley SJ, Wells AU, Hawtin KE, et al. Lung morphology in the elderly: comparative CT study of subjects over 75 years old versus those under 55 years old. Radiology 2009;251:566-573.
3. Flavia Angélica Ferreira Francisco1, Arthur Soares Souza Jr2, Multiple cystic lung disease, Eur Respir Rev 2015; 24: 552-564

4. Gupta N, Langenderfer D, McCormack FX, et al. Chest computed tomographic image screening for cystic lung diseases in patients with spontaneous pneumothorax is cost effective. Ann Am Thorac Soc 2017; 14:17-25

5. Gupta N, Vassallo R, WikenheiserBrokamp KA, McCormack FX. Diffuse cystic lung disease: part I. Am J Respir Crit Care Med 2015;191:1354-1366.

6. Hallifax RJ, Yousuf A, Jones HE, et al. Effectiveness of chemical pleurodesis in spontaneous pneumothorax recurrence prevention: a systematic review. Thorax 2016; Nov 1. pii: thoraxjnl-2015-207967. doi: 10.1136/thoraxjnl- 2015-207967

7. Hansell DM, Bankier AA, MacMahon H, McLoud TC, Muller NL, Remy J. Fleischner Society: glossary of terms for thoracic imaging. Radiology 2008;246:697-722.

8. Johannesma PC, Reinhard R, Kon Y, et al. Prevalence of Birt-Hogg-Dube syndrome in patients with apparently primary spontaneous pneumothorax. Eur Respir J 2015; 45:1191-1194.

9. Joseph Cooleya, Yun Chor Gary Leeb,c,d, and Nishant Gupta, Spontaneous pneumothorax in diffuse cystic lung diseases, Curr Opin Pulm Med 2017, 23:323-333

10. Kadota Y, Fukui E, Kitahara N, et al. Total pleural covering technique for intractable pneumothorax in patient with Ehlers-Danlos syndrome. Gen Thorac Cardiovasc Surg 2016; 64:425-428. 
11. Kurihara M, Mizobuchi T, Kataoka Years Old Woman With Pulmonary $\mathrm{H}$, et al. A total pleural covering for lymphangioleiomyomatosis: Insights and lymphangioleiomyomatosis prevents Pitfalls of the Surgical Treatment, J Clin Med pneumothorax recurrence. PLoS One 2016; Res $2013 ; 5(1): 70-74$ 11:e0163637.

14. Noda M, Okada Y, Maeda S, et al. A

12. Kwon YS, Han J, Jung KH, Kim JH, total pleural covering technique in patients with Koh WJ. Mycobacterium avium lung disease intractable bilateral secondary spontaneous combined with a bronchogenic cyst in an pneumothorax: report of five cases. Surg Today immunocompetent young adult. Korean J In- 2011;41:1414-1417.

tern Med 2013;28:94-97.

13. Kyriakos Spiliopoulosa, e, Angeliki Tsantsaridoua, Rodula Papamichalib, Recurrent Spontaneous Pneumothorax in a 42

15. Sanghoon Park1 and Eun Joo Lee2, v Diagnosis and treatment of cystic lung disease, Korean J Intern Med 2017; 32 : 229-238. 